\title{
PERBANDINGAN NILAI AGREGASI TROMBOSIT PADA PASIEN DIABETES MELITUS TIPE 2 DENGAN DISLIPIDEMIA DAN NORMOLIPIDEMIA DI RSUP PROF. DR. R. D. KANDOU MANADO
}

\author{
${ }^{1}$ Ivan Ch. Sulamanda \\ ${ }^{2}$ George A. Mantiri \\ ${ }^{2}$ Maya F. Memah
}

\author{
${ }^{1}$ Kandidat Skripsi Fakultas Kedokteran Universitas Sam Ratulangi Manado \\ ${ }^{2}$ Bagian Patologi Klinik Fakultas Kedokteran Universitas Sam Ratulangi Manado \\ Email: ivansulamanda10_113@yahoo.com
}

\begin{abstract}
Insulin resistance that occurs in patients with type 2 diabetes mellitus (T2DM), stimulates lipolysis in adipose tissue resulting in increasing of free fatty acid and dyslipidemia. Dyslipidemia is associated with platelet reactivity and thrombogenic potency. Examination of platelet aggregation aims to detect abnormalities of platelet function. This study aimed to obtain the comparison of platelet aggregation values in T2DM patients with dyslipidemia and with normal blood lipid level. This was an observational analytical study, using comparative hypothesis test. This study were conducted on 30 T2DM patients, in which 15 of them have dyslipidemia and the other 15 has normal lipid level. These patients were registered as outpatients of Endocrine and Metabolic Clinic of Prof. Dr. R. D. Kandou Hospital, Manado. Blood samples of patients were processed in Prokita Laboratory, Manado. Platelet aggregation was tested by using 1 set agregometer Chrono - Log model 490, Chrono - Log recorder model 707, and Computer Windows based PC. The T test showed that there were significant differences of the platelet aggregation values with ADP $10 \mu \mathrm{m}$ agonist between T2DM patients with dyslipidemia and with normal blood lipid level $(P=0.019)$. Mann-Whitney test showed that there were significant differences of the platelet aggregation values with ADP $5 \mu \mathrm{m}$ agonist between T2DM patients with dyslipidemia and with normal blood lipid level $(P=0.006)$. Most patients in this study were elderly (86.7\%), with an equal number of men and women. Conclusion: There were significant differences of the platelet aggregation values between T2DM patients with dyslipidemia and with normal blood lipid level, whether using ADP $10 \mu \mathrm{m}$ agonist or ADP $5 \mu \mathrm{m}$ agonist.
\end{abstract}

Keywords: platelet aggregation, T2DM, dyslipidemia

\begin{abstract}
Abstrak: Pada pasien diabetes melitus tipe 2 (DMT2), resistensi insulin merangsang lipolisis di jaringan adiposa yang meningkatkan asam lemak bebas sehingga terjadi dislipidemia. Dislipidemia sering dikaitkan dengan peningkatan aktivitas platelet dan potensi trombogenik. Pemeriksaan agregasi trombosit bertujuan untuk mendeteksi abnormalitas fungsi trombosit. Penelitian ini bertujuan untuk melihat perbandingan nilai agregasi trombosit pada pasien DMT2 dengan dislipidemia dan normolipidemia. Penelitian ini bersifat observasional analitik dengan menggunakan metode uji hipotesis komparatif. Subjek penelitian berjumlah 30 orang, terdiri dari 15 pasien DMT2 dengan dislipidemia dan 15 pasien DMT2 dengan normolipidemia yang berobat ke Poliklinik Endokrin Metabolik RSUP Prof. Dr. R. D. Kandou Manado. Pemeriksaan sampel darah pasien dilakukan di Laboratorium Prokita Manado. Pemeriksaan agregasi trombosit menggunakan 1 set agregometer Chrono - Log model 490, Chrono - Log recorder model 707, Computer Windows based PC. Karakteristik terbanyak pada pasien DMT2 terdapat pada usia tua $(86,7 \%)$ dengan jenis kelamin laki laki dan perempuan sama banyak (50\%). Hasil uji T menunjukkan terdapat perbedaan bermakna antara nilai agregasi trombosit menggunakan agonis ADP $10 \mu \mathrm{m}$ pada pasien DMT2 dengan dislipidemia dan normolipidemia $(P=0,019)$. Uji Mann-Whitney juga menunjukkan terdapat perbedaan bermakna antara nilai agregasi trombosit dengan agonis ADP $5 \mu \mathrm{m}$ pada pasien DMT2
\end{abstract}


dengan dislipidemia dan normolipidemia $(P=0,006)$. Simpulan: Terdapat perbedaan bermakna antara nilai agregasi trombosit pada pasien DMT2 dengan dislipidemia dan normolipidemia baik menggunakan agonis ADP $10 \mu \mathrm{m}$ maupun ADP $5 \mu \mathrm{m}$.

Kata kunci: agregasi trombosit, DMT2, dislipidemia

DMT2 merupakan penyakit kronis yang disebabkan oleh warisan atau diperoleh dari kekurangan produksi insulin oleh pankreas, atau dengan tidak efektifnya insulin yang diproduksi, oleh karena itu terjadi peningkatan konsentrasi glukosa dalam darah, yang pada akhirnya merusak banyak sistem tubuh, khususnya pembuluh darah dan saraf. ${ }^{1}$

Pada abad ke-21, DMT2 merupakan salah satu masalah kesehatan yang serius dan terus berkembang. ${ }^{2}$ Pada tahun 2011 terdapat 366 juta jiwa yang menderita penyakit DMT2 dan diperkirakan akan terus meningkat mencapai 552 juta jiwa pada tahun 2030. ${ }^{3}$ Di tahun 2012 lebih dari 371 juta jiwa yang menderita penyakit DMT2, jumlah orang yang menderita penyakit ini terus meningkat di berbagai negara, setengah dari penderita penyakit ini tidak terdiagnosa, 4,8 juta jiwa yang mengidap penyakit DMT2 ini meninggal, dan lebih dari 471 milyar dollar Amerika dihabiskan untuk menangani penyakit DM ini. $^{4}$

Indonesia kini telah menduduki rangking keempat jumlah penyandang DMT2 terbanyak setelah Amerika Serikat, China dan India. Berdasarkan data dari Badan Pusat Statistik (BPS) jumlah penyandang DMT2 pada tahun 2003 sebanyak 13,7 juta orang dan berdasarkan pola pertambahan penduduk diperkirakan pada 2030 akan ada 20,1 juta penyandang diabetes, WHO memprediksi kenaikan jumlah penyandang DMT2 di Indonesia dari 8,4 juta pada tahun 2000 menjadi sekitar 21,3 juta pada tahun $2030 .^{5}$

Pada pasien DMT2 terjadi abnormalitas trombosit yaitu peningkatan agregasi dan adhesi dari trombosit. ${ }^{6}$ Peningkatan agregasi trombosit yang direspon dengan adenosine difosfat (ADP), trombin, kolagen, asam arakidonat, dan epinefrin terlihat pada pasien DMT2 dibandingkan dengan orang yang tidak menderita DMT2. Pada kondisi in vitro trombosit ini distimulasi dengan agonis trombosit dan menunjukkan penurunan ambang batas tahanan untuk trombosit beragregasi. $^{7}$

Beberapa mekanisme yang diduga berperan dalam peningkatan reaktivitas trombosit antara lain disebabkan oleh kelainan metabolisme dan selular yaitu hiperglikemi, resistensi insulin, dan kondisi - kondisi metabolik yang berkaitan dengan penyakit DMT2 seperti obesitas, dislipidemia, dan peningkatan inflamasi, serta kelainan - kelainan selular lainnya. Disfungsi endotel, hiperaktivitas trombosit, gangguan keseimbangan fibrinolitik, keabnormalan aliran darah memungkinkan peningkatan aterosklerosis dan resiko kejadian trombosis vaskular. Pada DMT2 terjadi perubahan distribusi lipid yang meningkatkan resiko aterosklerosis. Keadaan ini ditandai dengan trigliserida plasma yang tinggi, kolesterol high density lipoprotein (HDL) yang rendah, dan meningkatnya kolesterol low density lipoprotein (LDL), ${ }^{6,8,9}$

Disregulasi transportasi dan metabolisme kolestrol merupakan faktor resiko penting untuk terjadinya aterosklerosis dan keterkaitan dengan meningkatnya reaktivitas trombosit, namun mekanisme molekular yang menghubungkan hiperkolesterolemia dan peningkatan fungsi trombosit masih diteliti lebih lanjut. ${ }^{10}$

\section{METODE PENELITIAN}

Penelitian ini bersifat observasional analitik dengan menggunakan metode uji hipotesis komparatif dan dilaksanakan di Poliklinik Endokrin - Metabolik bagian Penyakit Dalam RSUP Prof. Dr. R. D. Kandou Manado. Pemeriksaan agregasi trombosit dilakukan di Laboratorium Prokita Manado. Pemeriksaan agregasi trombosit menggunakan 1 set agregometer 
Chrono - Log model 490, Chrono - Log recorder model 707, Computer Windows based PC. Penelitian dilakukan sejak November 2013 sampai Februari 2014. Sampel penelitian yaitu 15 penyandang DMT2 dengan dislipidemia dan 15 penyandang DMT2 dengan normolipidemia yang termasuk kriteria inklusi. Data dianalisis dengan uji T dan uji MannWhitney.

\section{HASIL PENELITIAN}

Subjek penelitian ini berjumlah 30 orang. Jumlah penyandang DMT2 dengan dislipidemia dan yang dengan normolipidemia sama banyak yaitu masingmasing 15 orang (50\%) (Tabel 1).

Usia yang termasuk dalam kriteria inklusi ialah 40 - 80 tahun. Pada penelitian ini ditemukan lebih banyak subjek yang berusia tua $(86,7 \%)$ dibandingkan usia dewasa (13,3\%) (tabel 1).

\section{Data nilai agregasi trombosit pada penyandang DMT2 dengan dislipidemia}

Data nilai agregasi trombosit pada penyandang DMT2 dengan dislipidemia dapat dilihat pada Tabel 2. Nilai agregasi trombosit pada DMT2 dengan dislipidemia yang menggunakan ADP $10 \mu \mathrm{m}$ terendah yaitu $28 \%$ dan tertinggi yaitu $67 \%$, sehingga diperoleh nilai rata - rata sebesar 48,07\% (dibulatkan 48\%) dengan simpang baku 10,78\%. Pada nilai agregasi trombosit dengan menggunakan ADP $5 \mu \mathrm{m}$ terendah yaitu 30\% dan tertinggi yaitu 106\%, sehingga diperoleh nilai rata - rata sebesar $56,27 \%$ (dibulatkan 56\%) dengan simpang baku 24,99\%.

\section{Data nilai agregasi trombosit pada penyandang DMT2 dengan normo- lipidemia}

Data nilai agregasi trombosit pada DMT2 dengan normolipidemia dapat dilihat pada Tabel 3. Nilai agregasi trombosit dengan menggunakan ADP 10 $\mu \mathrm{m}$ terendah yaitu $16 \%$ dan tertinggi yaitu $68 \%$, sehingga diperoleh nilai rata - rata sebesar 35,60\% (dibulatkan 36\%) dengan simpang baku 13,85\%. Pada nilai agregasi trombosit dengan menggunakan ADP 5 $\mu \mathrm{m}$ terendah yaitu $9 \%$ dan tertinggi yaitu $66 \%$, sehingga diperoleh nilai rata - rata sebesar 32,20\% (dibulatkan 32\%) dengan simpang baku 17,45\%.

\section{Analisis perbandingan nilai agregasi trombosit pada penyandang DMT2 dengan dislipidemia dan normo- lipidemia}

Perbandingan nilai agregasi trombosit pada DMT2 dengan dislipidemia dan normolipidemia dapat dilihat pada Tabel 4 dan 5. Uji normalitas data didapatkan distribusi normal pada ADP 10 $\mu \mathrm{m}$ dan tidak normal pada ADP $5 \mu \mathrm{m}$. Analisis uji $\mathrm{T}$ dua variabel pada DMT2 dengan dislipidemia dan normolipidemia menggunakan ADP $10 \mu \mathrm{m}$, menunjukkan nilai kemaknaan $P<0,0$ yaitu 0,019 . Analisis uji Mann-Whitney dua variabel pada DMT2 dengan dislipidemia dan normolipidemia menggunakan ADP $5 \mu \mathrm{m}$, menunjukkan nilai kemaknaan $P<0,05$ yaitu 0,006 .

\section{BAHASAN}

Pada penelitian ini jumlah subjek penelitian yang memenuhi kriteria inklusi ialah 30 orang di Poliklinik Endokrin Metabolik Bagian Penyakit Dalam RSUP. Prof. Dr. R. D. Kandou Manado lalu diambil sampel darahnya dan diperiksa nilai agregasi trombositnya di laboratorium Prokita Manado.

Menurut $\mathrm{WHO}^{1}$ peningkatan prevalensi usia pasien DMT2 di negara berkembang yaitu 45 tahun keatas, dan bertambahnya usia merupakan salah satu faktor resiko terjadinya penyakit DMT2. Hasil penelitian ini menunjukkan jumlah usia tua ( $\geq 50$ tahun) lebih banyak dibandingkan usia dewasa $\$ 49$ tahun). Pada penelitian ini jenis kelamin baik laki - laki maupun perempuan memiliki jumlah yang sama banyak yaitu masing - masing berjumlah 15 orang. 
Tabel 1. Karakteristik Subjek Penelitian Berdasarkan Usia dan Jenis Kelamin

\begin{tabular}{cccc}
\hline Karakteristik & Klasifikasi & Frekuensi & Persentasi \\
\hline \multirow{2}{*}{ Usia } & Dewasa ( $\leq 49$ Tahun) & 4 & $13,3 \%$ \\
& Tua ( $\geq 50$ Tahun) & 26 & $86,7 \%$ \\
\multirow{2}{*}{ Jenis Kelamin } & Laki - laki & 15 & $50 \%$ \\
& Perempuan & 15 & $50 \%$ \\
\hline
\end{tabular}

Tabel 2. Data Nilai Agregasi Trombosit pada DMT2 dengan Dislipidemia

\begin{tabular}{ccccc}
\hline Variabel & $\begin{array}{c}\text { Nilai } \\
\text { Terendah }\end{array}$ & $\begin{array}{c}\text { Nilai } \\
\text { Tertinggi }\end{array}$ & $\begin{array}{c}\text { Nilai Rata - } \\
\text { rata }\end{array}$ & $\begin{array}{c}\text { Simpang } \\
\text { Baku }\end{array}$ \\
\hline $\begin{array}{c}\text { DMT2 dengan dislipidemia } \\
(\text { ADP } 10 \mu \mathrm{m})\end{array}$ & $28 \%$ & $67 \%$ & $48,07 \%$ & $10,78 \%$ \\
$\begin{array}{c}\text { DMT2 dengan dislipidemia } \\
(\text { ADP } 5 \mu \mathrm{m})\end{array}$ & $30 \%$ & $106 \%$ & $56,27 \%$ & $24,99 \%$ \\
\hline
\end{tabular}

Tabel 3. Data Nilai Agregasi Trombosit pada DMT2 dengan Normolipidemia

\begin{tabular}{ccccc}
\hline Variabel & $\begin{array}{c}\text { Nilai } \\
\text { Terendah }\end{array}$ & $\begin{array}{c}\text { Nilai } \\
\text { Tertinggi }\end{array}$ & $\begin{array}{c}\text { Nilai Rata - } \\
\text { rata }\end{array}$ & $\begin{array}{c}\text { Simpang } \\
\text { Baku }\end{array}$ \\
\hline $\begin{array}{c}\text { DMT2 dengan normolipidemia } \\
\text { (ADP 10 } \mu \mathrm{m})\end{array}$ & $16 \%$ & $68 \%$ & $35,60 \%$ & $13,85 \%$ \\
$\begin{array}{c}\text { DMT2 dengan normolipidemia } \\
(\text { ADP 5 } \mu \mathrm{m})\end{array}$ & $9 \%$ & $66 \%$ & $32,20 \%$ & $17,45 \%$ \\
\hline
\end{tabular}

Tabel 4. Perbandingan Nilai Agregasi Trombosit dengan Menggunakan ADP $10 \mu \mathrm{m}$ pada Pasien DMT2 dengan Dislipidemia dan Normolipidemia

\begin{tabular}{ccc}
\hline Variabel & Kategori & Nilai p \\
\hline Nilai Agregasi Trombosit & $\begin{array}{c}\text { DMT2 dengan dislipidemia } \\
\text { (ADP } 10 \mu \mathrm{m})\end{array}$ & 0,019 \\
& $\begin{array}{c}\text { DMT2 dengan normolipidemia } \\
(\text { ADP } 10 \mu \mathrm{m})\end{array}$ & \\
\hline
\end{tabular}

Tabel 5. Perbandingan Nilai Agregasi Trombosit dengan Menggunakan ADP $5 \mu \mathrm{m}$ pada DMT2 dengan Dislipidemia dan Normolipidemia

\begin{tabular}{ccc}
\hline Variabel & Kategori & Nilai p \\
\hline Nilai Agregasi Trombosit & $\begin{array}{c}\text { DMT2 dengan dislipidemia } \\
(\text { ADP } 5 \mu \mathrm{m})\end{array}$ & 0,006 \\
& $\begin{array}{c}\text { DMT2 dengan normolipidemia } \\
(\text { ADP } 5 \mu \mathrm{m})\end{array}$ & \\
\hline
\end{tabular}


Interpretasi nilai normal yang digunakan oleh peneliti menggunakan standar nilai normal Laboratorium Prokita Manado yaitu: nilai ADP $10 \mu \mathrm{m}$ 49-84\% dan nilai ADP $5 \mu \mathrm{m}$ 25-68\%. Pada penelitian ini, interpretasi nilai agregasi trombosit untuk DMT2 dengan dislipidemia ialah: 4 orang hiperagregasi, 3 orang normoagregasi, dan 8 orang hipoagregasi. Nilai agregasi trombosit terendah menggunakan ADP $10 \mu \mathrm{m}$ 28\% dan nilai tertinggi $67 \%$, sedangkan nilai agregasi trombosit terendah menggunakan ADP $5 \mu \mathrm{m}$ 30\% dan nilai tertinggi 106\%.

Interpretasi nilai agregasi trombosit pada pasien DMT2 dengan dislipidemia didapatkan 8 orang yang interpretasinya hipoagregasi; hal ini bisa dikarenakan pengaruh obat antidiabetik. Menurut Siluk, beberapa obat anti diabetik yang mempunyai efek untuk menghambat agregasi trombosit misalnya dari golongan glimepirid, glicazide, glibenclamide, gliquidone, glipolamide, chlorpropamide, glipicide, tolbutamide dan insulin yang dapat meningkatkan proses fibrinolisis. ${ }^{11}$

Interpretasi nilai agregasi trombosit pada DMT2 dengan normolipidemia didapatkan: 1 orang normoagregasi dan 14 orang hipoagregasi. Nilai agregasi trombosit terendah menggunakan ADP 10 $\mu \mathrm{m} 16 \%$ dan nilai tertinggi $68 \%$, sedangkan nilai agregasi trombosit terendah menggunakan ADP $5 \mu \mathrm{m}$ 9\% dan nilai tertinggi $66 \%$.

Perbandingan interpretasi nilai agregasi trombosit pada DMT2 dengan dislipidemia dan normolipidemia didapatkan bahwa terdapat 4 orang pasien dengan hasil hiperagregasi pada DMT2 dengan dislipidemia, sedangkan pada normolipidemia tidak terdapat pasien dengan hasil hiperagregasi melainkan terdapat 14 pasien yang hasilnya hipoagregasi. Perbedaan hasil interpretasi ini dapat disebabkan oleh abnormalitas fungsi trombosit pada dislipidemia yang mengakibatkan peningkatan ekspresi molekul - molekul trombosit, peningkatan reseptor permukaan trombosit, ditambah dengan penurunan kadar insulin yang meningkatkan respon trombosit terhadap ADP dan kelainan abnormalitas selular lainnya. ${ }^{6,9,12}$

Nilai rata - rata agregasi trombosit pada DMT2 dengan dislipidemia dan normolipidemia yang menggunakan ADP $10 \mu \mathrm{m}$ menunjukkan bahwa nilai agregasi trombosit pada DMT2 dengan dislipidemia didapatkan lebih tinggi 48,07\% dibandingkan dengan normolipidemia 35,60\%. Dengan menggunakan ADP $5 \mu \mathrm{m}$ nilai agregasi trombosit pada pasien DMT2 dengan dislipidemia juga didapatkan lebih tinggi 56,27\% dibandingkan dengan normolipidemia 32,20\%, yang berarti secara nominal terdapat perbedaan antara kedua variabel.

Pada uji $\mathrm{T}$, nilai agregasi trombosit pada DMT2 dengan dislipidemia dan normolipidemia dengan ADP $10 \mu \mathrm{m}$ didapatkan nilai kemaknaan $P<0,05$ yaitu 0,019, sedangkan dengan ADP $5 \mu \mathrm{m}$ menggunakan uji Mann-Whitney didapatkan nilai kemaknaan $P<0,05$ yaitu 0,006 . Hasil ini menunjukkan bahwa terdapat perbedaan nilai agregasi trombosit pada DMT2 dengan dislipidemia dan normolipidemia.

Hasil penelitian ini memiliki simpulan yang sama dengan penelitian Ferreiro. et al. ${ }^{12}$ yang menyatakan bahwa DMT2 berperan penting dalam hiperaktivasi trombosit. Penelitian Ferreiro menggunakan aktivasi platelet P-selectin dan CD40 ligand pada pasien DMT2 dan pada orang non DMT2 menyatakan bahwa reaktivasi platelet pada pasien dengan DMT2 lebih meningkat dibandingkan orang non DMT2. Pasien dengan DMT2 sering mengalami masalah komplikasi makrovaskular dan mikrovaskular seperti aterosklerotik kardiovaskular dan strok. ${ }^{9,13}$

Hasil penelitian yang sama dengan penelitian-penelitian sebelumnya menunjukkan bahwa terdapat perbedaan nilai agregasi trombosit pada DMT2 dengan dislipidemia dibandingkan DMT2 dengan normolipidemia. Hal ini dapat dilihat dari 
nilai agregasi trombosit pada DMT2 dengan dislipidemia lebih tinggi dibandingkan DMT2 dengan normolipidemia.

Keterbatasan penelitian ini ialah: terbatasnya jumlah sampel, penggunaan berbagai macam jenis obat antiodaibetik yang dipakai subjek penelitian, kadar agonis ADP yang digunakan $5 \mu \mathrm{m}$ dan 10 $\mu \mathrm{m}$, dan waktu penelitian yang singkat untuk pengumpulan dan pengolahan sampel.

\section{SIMPULAN}

Berdasarkan hasil penelitian ini maka dapat disimpulkan bahwa terdapat perbedaan bermakna antara nilai agregasi trombosit pada pasien DMT2 dengan dislipidemia dan normolipidemia baik yang menggunakan agonis ADP $10 \mu \mathrm{m}$ maupun agonis ADP $5 \mu \mathrm{m}$. Nilai rerata agregasi trombosit pada pasien DMT2 dengan dislipidemia lebih tinggi dibandingkan pasien DMT2 dengan normolipidemia.

\section{SARAN}

Untuk penelitian lanjutan, jumlah sampel penelitian perlu ditingkatkan untuk menghindari terjadinya bias dalam penelitian. Dapat juga digunakan berbagai kadar agonis ADP $(1,2$, 5, dan $10 \mu \mathrm{m})$ agar ketelitian interpretasi nilai agregasi trombosit lebih efektif. Penelitian ini dapat dilakukan pada penyakit - penyakit yang berhubungan dengan gangguan vaskular seperti pada penyakit jantung koroner dan strok.

\section{DAFTAR PUSTAKA}

1. World Health Organization. Diabetes Mellitus. 2013. [Cited 7 September 2013]. Available: http://www.who.int/mediacentre/factsheet s/fs138/en/.
2. International Diabetes Federation. Global diabetes plan 2011-2021. 2011. [Cited 7 September 2013]. Available: http://www.idf.orf/sites/default/files/Glob alDiabetes_Plan_Final.pdf.

3. International Diabetes Federation. IDF Diabetes Atlas Foreword. 2011. [Cited 7 September 2013]. Available: http://www.idf.org/diabetesatlas/5e/forew ord.

4. International Diabetes Federation. IDF Diabetes Atlas Update 2012. 2012. [Cited 7 September 2013]. Available: http://www.idf.org/diabetesatlas/5e/Updat e2012.

5. Pusat data dan Informasi PERSI. RI Rangking Keempat Jumlah Penderita Diabetes Tebanyak Dunia. 2011. [Cited 7 September 2013]. Available: http://www.pdpersi.co.id/content/news.ph p?mid=5\&nid=618\&catid=23.

6. Huri HZ. Dyslipidemia and type 2 diabetes mellitus : implication and role of antiplatelet agents in primary prevention of cardiovascular disease. 2012. [Cited 4 September 2013]. Available: http://cdn.intechopen.com/pdfs/27493/InT ech-

Dyslipidemia_and_type_2_diabetes_melli tus_implications_and_role_of_antiplatelet _agents_in_primary_prevention_of_cardi ovascular_disease.pdf.

7. Saboor M, Moinuddin, Ilyas S. : Platelets structural, functional, and metabolic alterations in diabetes mellitus. 2012. [Cited 7 September 2013]. Available: http://www.pps.org. pk/PJP/82/Saboor.pdf.

8. Kodiatte TA, Manikyam UK, Rao SB, Jagadish TM, Redde M, Lingaiah HK, dkk. Mean platelet volume in type 2 diabetes mellitus. J Lab Physicians. 2012;4:5-9.

9. Stratmann B, Tschoepe D. Pathobiology and cell interactions of platelets in diabetes. Diabetes and Vascular Research. 2005;2:16-23. 
10. Kaplan ZS, Jackson SP. : SR-BI and fatty platelets. 2010. [Cited 7 September 2013]. Available: http://bloodjournal. hematologylibrary.org/content/116/11/182 7.full.

11. Prima A. Perbedaan pola gangguan hemostasis antara penyakit ginjal kronik prehemodialisis dengan diabetes mellitus dan non diabetes mellitus (Tesis).
Semarang: Fakultas Kedokteran Universitas Diponegoro; 2008.

12. Ferreiro JS, Gomez JA, Angiolillo D. Platelet abnormalities in diabetes mellitus. Diabetes and Vascular Research. 2010;7:251-59.

13. Vinik AI, Erbas T, Park TS, Nolan R, Pittenger GL. Platelet dysfunction in type 2 diabetes. Diabetes Care. 2001;24:1476-85. 